УДК 346.1

DOI https:/ / doi.org/10.32837/yuv.v0i3.1955

\author{
О. Іванов,
}

аспірант кафедри цивільно-господарського права та процесу

Академії адвокатури України

\title{
ЗАГАЛЬНІ ПРОЦЕСУАЛЬНІ ПРАВА ТА ОБОВ'ЯЗКИ УЧАСНИКІВ СПРОЩЕНОГО ПОЗОВНОГО ПРОВАДЖЕННЯ
}

\begin{abstract}
Спрощене позовне провадження у господарському процесу можна визначити як самостійну процесуальну форму господарського судочинства, метою якої є оперативне вирішення господарських спорів, розгляд яких у загальному провадженні $€$ недоцільним і неефективним, сутність якої полягає у спрощенні загальної позовної судової процедури на підставі малозначності вимог.

Питання судового захисту та відновлення своїх законних інтересів, прав і свобод, а також забезпечення реалізації законних інтересів, прав та свобод людини $є$ чи не одним 3 найгостріших питань, тому слід чітко розуміти обсяг прав і обов'язків учасників судового процесу, які виникають при використанні механізму судового захисту у вигляді спрощеного позовного провадження.
\end{abstract}

Мета статті - висвітити загальні процесуальні права та обов'язки учасників спрощеного позовного провадження.

Виклад основного матеріалу. Стаття 56 Конституції України [1] $€$ гарантією того, що суд повинен відповідно до закону докладати усіх зусиль, щоб захистити та відновити порушені законні інтереси, права та свободи людини або забезпечити реалізацію іï законних інтересів, прав і свобод.

Фундаментальною статтею $€$ стаття 57 Конституції України, оскільки вона визначає мету написання всього розділу, тобто саме окреслення базових процесуальних прав як загальних, так і спеціальних учасників спрощеного позовного провадження та їх аналіз дасть змогу учасникам спрощеного позовного провадження швидко, ефективно використати такий спосіб вирішення справи.

Стаття 59 Конституції України останніми роками зазнавала змін, однак вона стосується невід'ємного учасника в процесі - особи, яка має право надавати професійну правничу допомогу. Так, одним із ключових учасників судового процесу $€$ представник. Тому визначення його процесуальних прав і обов'язків дає можливість особі, яку він представляє, отримати максимально можливий спектр засобів реалізації захисту та відновлення порушених законних інтересів, прав і свобод людини або забезпечення реалізації іi законних інтересів, прав і свобод.

Інші статті, а саме 63, 64, 67, 68 Конституції України не потребують особливого аналізу, оскільки вони $€$ більш декларативними та мають на меті встановлення дозволеної міри поведінки (зобов'язуючі норми права) або надання можливості обрати бажаний спосіб поведінки (правонаділяючі норми права).

Пропонуємо перейти до наступного нормативного правового акту, який детально прописує процесуальні права та обов'язки учасників у спрощеному позовному провадженні - Господарського процесуального кодексу України [2]. 
Так, згідно зі статтею 4 Господарського процесуального кодексу України [2] право на звернення до господарського суду в установленому порядку гарантується Господарським процесуальним кодексом України. Ніхто не може бути позбавлений права на розгляд його справи у господарському суді, до юрисдикції якого вона віднесена законом. Жодна особа не може бути позбавлена права на участь у розгляді своєї справи у визначеному законом порядку.

Аналізуючи цю статтю, слід зробити висновок, що вона $є$ логічним продовженням згаданих вище статей, які містяться в Конституції України [1, р. № 254к/96-ВР] щодо обов'язку держави захистити, відновити та забезпечити реалізацію законних інтересів, прав і свобод людини та скористатися правом особи, яка згодом стане учасником справи в порядку спрощеного позовного провадження і набуде додаткових процесуальних прав і обов'язків відповідно до чинного законодавства України.

Вадливим загальним правом учасників спрощеного провадження, на нашу думку, $є$ право бути своєчасно повідомленим про власні права, передбачені ГПК України, а також отримати ї роз'яснення. Так, згідно зі статтею 205 ГПК України [2] за клопотанням учасника справи головуючий роз'яснює йому права та обов'язки, крім випадків, коли учасника справи представляє адвокат. Водночас статтею 255 ГПК України встановлено, що протокол вчинення окремої процесуальної дії має містити відомості про роз'яснення учасникам справи їх процесуальних прав та обов'язків.

Згідно зі статтею 6 ГПК України у господарських судах функціонує Єдина судова інформаційно-телекомунікаційна система (далі - ЄCITC). Єдина судова інформаційно-телекомунікаційна система відповідно до закону забезпечує обмін документами (надсилання та отримання докумен- тів) в електронній формі між судами, між судом та учасниками судового процесу, між учасниками судового процесу, а також фіксування судового процесу і участь учасників судового процесу у судовому засіданні в режимі відео конференції [2].

Можна виокремити такі функції ECITC: подання заяв і документів до суду в електронній формі, автоматизований розподіл справ, обмін документами між всіма учасниками процесу в електронній формі, аудіо- та відеофіксація судових засідань, направлення судового рішення за електронним цифровим підписом судді на офіційну зареєстровану адресу сторін тощо [3, с. 139-140]. Т.В. Степанова пропонує визначити загальне право учасників провадження на те, як користуватися електронними (цифровими) технологіями при реалізації своїх прав [4, с. 169].

Згідно зі статтею 7 ГПК України правосуддя в господарських судах здійснюється на засадах рівності всіх юридичних осіб незалежно від організаційно-правової форми, форми власності, підпорядкування, місцезнаходження, місця створення та реєстрації, законодавства, відповідно до якого створена юридична особа, та інших обставин; рівності всіх фізичних осіб незалежно від раси, кольору шкіри, політичних, релігійних та інших переконань, статі, етнічного і соціального походження, майнового стану, місця проживання, мовних або інших ознак; рівності фізичних та юридичних осіб незалежно від будь-яких ознак чи обставин.

Аналізуючи цю статтю, слід зробити висновок, що кожна юридична та фізична особа має право бути рівною перед судом і законом, жоден не може бути звужений у своїх процесуальних правах, а повинен мати розширений обсяг обов'язків.

Згідно зі статтею 8 ГПК України ключовими правами та обов'язками є право бути присутнім у відкритому судовому засіданні; право 
проводити у залі судового засідання фотозйомку, відео- та аудіозапис з використанням портативних відео- та аудіотехнічних засобів без отримання окремого дозволу суду, але з урахуванням обмежень, встановлених законодавством України; користуючи вищезазначені права обов'язок не створювати перешкоди у веденні засідання і здійсненні іншими учасниками судового процесу їхніх процесуальних прав; право на закрите судове засідання або вчинення окремих процесуальних дій, які відбуваються в закритому судовому засіданні, у порядку, визначеному законодавством України; обов'язок не розголошувати інформацію, для забезпечення захисту якої розгляд справи або вчинення окремих процесуальних дій, які відбуваються в закритому судовому засіданні.

Згідно зі статтею 9 ГПК України [2], яка охоплює питання поінформованості особи, зокрема учасників спрощеного позовного провадження щодо розгляду справи в суді, а саме: право на інформацію про дату, час i місце розгляду своєї справи; право на отримання в суді усної або письмової інформації про результати розгляду його судової справи; право на доступ до судових рішень у порядку, встановленому законом.

Щодо осіб, які не брали участі у справі, тобто на момент розгляду справи не набули статусу учасника спрощеного позовного провадження, якщо суд вирішив питання про їхні права, інтереси та (або) обов'язки, які подали апеляційну чи касаційну скаргу на відповідне рішення, мають право на ознайомлення 3 матеріалами справи, робити з них витяги, знімати копії з документів, долучених до справи, одержувати копії судових рішень в порядку, передбаченому законодавством України

Важливою складовою процесуального статусу учасників позовного провадження слід визнати право на доступ до інформації, що перебуває у розпорядженні суду. Вказаному праву корелює обов'язок господарського суду надавати інформацію, необхідну для всебічного, повного та об'єктивного дослідження всіх обставин господарської справи. 3 одного боку, суд визначається 3 належністю, допустимістю та достовірністю доказів та долучає їх до справи, з іншого боку, учасники позовного провадження повинні мати доступ до всіх матеріалів, документів та іншої інформації, що перебуває у розпорядженні господарського суду [4, c. 169].

Є. Пілат слушно виділяє у складі права на доступ до інформації такі елементи (правомочності), які можуть бути реалізовані всіма без винятку суб'єктами зазначеного права: право доступу до документів та інших матеріалів, інформаційних ресурсів та інформаційних систем; право на звернення за інформацією до певних суб'єктів; право отримувати інформацію від конкретних суб'єктів; право фіксувати інформацію, у тому числі за допомогою технічних засобів; право на відтворення інформації (отриманої у не заборонений законом спосіб); право на доведення інформації до конкретних суб'єктів через іiі опублікування, а також поширення через мережі обміну даними (зокрема Інтернет), передачі через засоби масової інформації в режимі повідомлень; право на отримання консультації з питань доступу до інформації [5, c. 131].

Отже, «інформативні» права особи $€$ невід'ємною складовою забезпечення дієвого механізму реалізації права судового захисту та відновлення порушених законних інтересів, прав і свободи людини або забезпечення реалізації законних інтересів, прав та свобод людини, оскільки тільки при повному розумінні що відбувається при розгляді справи і як вона вирішена, можна зрозуміти тактику найкращого захисту та відновлення порушених своїх законних інтересів, 
прав і свободи або забезпечення реалізації своїх законних інтересів, прав та свобод людини.

Стаття 10 ГПК України охоплює питання права щодо використання державної мови під час судового процесу та надання особі рівних для реалізації прав і обов'язків можливостей у разі якщо є потреба у використанні іноземної мови. Так, в статті міститься застереження щодо заборони дискримінації будь-кого під час судового процесу, обов'язок дотримання цього застереження покладається на суддю, який наділений адміністративним ресурсом, який застосовується у вигляді санкцій до особи, що порушила дане застереження, а саме: штраф, попередження у вигляді зауваження тощо.

Окрім цього, суди зобов'язані використовувати державну мову в процесі судочинства, а також надають право учасникам судового процесу на використання ними в судовому процесі рідної мови або мови, якою вони володіють.

Учасники провадження мають рівні можливості в наданні пояснень та інших відомостей по справі, однак незнання мови в обсязі, необхідному для передачі складної інформації й викладу своєї позиції у справі, може стати серйозною перешкодою для реалізації конституційного принципу рівності усіх учасників судового процесу перед законом і судом [4, с. 169], встановленого ст. 129 Конституції України.

Згідно зі статтею 11 ГПК України, що закріплює верховенство права та детально визначає правила застосування норм права при вирішенні справ, важливим для нашої роботи $€$ положення щодо того, що особі не можливо відмовити у реалізації права на судовий захист через неповноту, неясність, суперечливість або відсутність законодавства, яке регулює спірні відносини.

Водночас, як нами вже зазначалось раніше, п. а частини 1 статтею 106
Закону України «Про судоустрій і статус суддів» закріплено можливість притягнення судді до дисциплінарної відповідальності в порядку дисциплінарного провадження з таких підстав у разі умисної або внаслідок недбалості незаконної відмови в доступі до правосуддя або іншого істотного порушення норм процесуального права під час здійснення правосуддя, що унеможливило реалізацію учасниками судового процесу наданих їм процесуальних прав та виконання процесуальних обов'язків або призвело до порушення правил щодо юрисдикції або складу суду [6].

Згідно зі статтею 13 ГПК України, учасники справ мають рівні права щодо здійснення всіх процесуальних прав та обов'язків, передбачених законодавством України, окрім цього, сторони судового процесу зобов'язані довести обставини, які мають значення для справи та на які сторони посилаються як на підставу своїх вимог або заперечень, крім випадків, встановлених законом.

Згідно зі статтею 14 ГПК України, особа має право на звернення до відповідного суду згідно з чинним законодавством України, яке обгрунтоване вимогами та доказами на підставі яких суд розглядатиме справу. Також слід зазначити, що учасник справи розпоряджається своїми правами щодо предмета спору на власний розсуд, аналогічне право мають також особи, в інтересах яких заявлено вимоги, за винятком тих осіб, які не мають процесуальної дієздатності відповідно до чинного законодавства.

Згідно зі статтею 16 ГПК України, кожному учаснику справи гарантується право на правничу допомогу, більш того, представництво в суді, як вид правничої допомоги, здійснюється виключно адвокатом, який здійснює професійну правничу допомогу, крім випадків, встановлених законом.

Стаття 17 ГПК України стосується права учасників справи та осіб, які не брали участі у справі, але суд 
вирішив питання про їхні права, інтереси та (або) обов'язки, на апеляційний перегляд справи та у визначених законом випадках - на касаційне оскарження судового рішення.

3 другої частини даної статті випливає обов'язок сторін та осіб, які не брали участі у справі, але суд вирішив питання про їні права, інтереси та (або) обов'язки, спершу використати апеляційний перегляд справи, а тільки потім звертатися до механізму касаційного оскарження судового рішення.

Згідно зі статтею 19 ГПК України, сторони вживають заходів для досудового врегулювання спору за домовленістю між собою або у випадках, коли такі заходи $€$ обов'язковими згідно із законом. Слід зазначити, що ця стаття $€$ «мертвою», оскільки були внесені зміни до ГПК України та перелік справ, що потребують обов'язкового досудового врегулювання спору вже не існує, окрім цього, не існує і порядку врегулювання «досудових» спорів.

В чинному ГПК України наявна тільки ст. 222, яка описує претензії як засіб врегулювання спору, однак, зараз господарські суди на підставі статті 19, п. 6 ч. 3 статті 162 та п. 6 ч. 5 статті 174 ГПК України відмовити в розгляді справи не можуть, оскільки це суперечить основоположному праву на доступ до правосуддя відповідно до статті 4 ГПК України, статті 55 Конституції України. Сумнівною є норма і про обов'язок особи, яка порушила права і законні інтереси інших осіб, зобов'язана поновити ix, не чекаючи пред'явлення претензії чи позову, оскільки законодавчого врегулювання щодо механізму забезпечення даної норми в реалії немає.

Завершуючи дане питання слід виокремити права та обов'язки, відповідно до статті 42 ГПК України [2], a саме:

1) ознайомлення 3 протоколом судового засідання, записом фіксування судового засідання технічними засобами, робити з них копії, подавати письмові зауваження з приводу ї неправильності чи повноти;

2) наведення своїх доводів, міркувань, клопотань з усіх питань, що виникають у ході судового процесу, заперечувати проти клопотань, заяв, міркувань та доводів інших учасників справи, на ознайомлення з матеріалами справи, виготовлення копій, витягів з них, отримувати копії судових рішень, ставити питання іншим учасникам справи, брати участь у дослідженні доказів, вказані права реалізувати, здебільшого, можливо у разі виклику сторін судом згідно 252 статті ГПК України;

3) добросовісно здійснювати свої процесуальні права і виконувати свої процесуальні обов'язки, дана норма реалізується через заборону зловживання своїми процесуальними правами відповідно до статті 43 ГПК України, а саме:

- заборона подання скарги на судове рішення, яке не підлягає оскарженню, не є чинним або дія якого закінчилася (вичерпана), подання клопотання (заяви) для вирішення питання, яке вже вирішено судом, за відсутності інших підстав або нових обставин, заявлення завідомо безпідставного відводу або вчинення інших аналогічних дій, спрямованих на безпідставне затягування чи перешкоджання розгляду справи чи виконання судового рішення;

- заборона подання декількох позовів до одного й того самого відповідача (відповідачів) 3 тим самим предметом та з тих самих підстав або подання декількох позовів з аналогічним предметом і 3 аналогічних підстав, або вчинення інших дій, метою яких $є$ маніпуляція автоматизованим розподілом справ між суддями;

- заборона подання завідомо безпідставного позову, позову за відсутності предмета спору або у спорі, який має очевидно штучний характер;

- заборона необгрунтованого або штучного об'єднання позовних вимог 
3 метою зміни підсудності справи, або завідомо безпідставне залучення особи як відповідача (співвідповідача) з тією самою метою;

- заборона укладення мирової угоди, спрямованої на шкоду правам третіх осіб, умисне неповідомлення про осіб, які мають бути залучені до участі у справі;

4) сприяти повному, всебічному, своєчасному та об'єктивному встановленню всіх обставин справи

5) з'являтися в судове засідання за викликом суду, якщо явка такої особи є обов'язкова

6) подавати усі наявні у них докази в порядку та строки, встановлені законом або судом, не приховувати докази;

7) надавати суду повні та достовірні пояснення 3 питань, які ставляться судом, а також учасниками справи в судовому засіданні;

8) виконувати процесуальні дії у встановлені законом або судом строки.

Отже, в статті було досліджено загальні прочесуальні права $i$ обов'язки учасників спрощеного позовного провадження в господарському проиесу крізь призму норм Конституиії України та Господарського процесуального кодексу України. Слід зазначити, що перелік $і$ обсяг прав $і$ обов'язків не є вичерпним та безмежним i тому окреслюється судом виходячи з конкретних обставин справи. Однак, саме ия "гнучкість» $i$ $\epsilon$ засобом забезпечення ефективного, справедливого, всебічного правосуддя, оскільки адаптуються прочесуальні права та обов'язки учасників справи відповідно до конкретних обставин справи та враховуючи чинне законодавство України.

Питання судового захисту та відновлення своїх законних інтересів, прав і свобод, а також забезпечення реалізаціі законних інтересів, прав та свобод людини є чи не одним з найгостріших питань, тому слід чітко розуміти обсяг прав і обов'язків учасників судового прочесу, які виникають при використанні механізму судового захисту у вигляді спрошеного позовного провадження. Згідно зі статтею 4 Господарського процесуального кодексу України, право на звернення до господарського суду в установленому порядку гарантується Господарським процесуальним кодексом України. Ніхто не може бути позбавлений права на розгляд його справи у господарському суді, до юрисдикції якого вона віднесена законом. Жодна особа не може бути позбавлена права на участь у розгляді своєї справи у визначеному законом порядку. Кожна юридична та фізична особа має право бути рівним перед судом $i$ законом, це означає, що жоден не може бути звужений у своїх проиесуальних правах і мати розширений обсяг обов'язків. Досліджено загальні процесуальні права та обов'язки учасників спрощеного позовного провадження в господарському прочесу крізь призму норм Конституиіі України та Господарського проиесуального кодексу України. Слід зазначити, що перелік $і$ обсяг прав $і$ обов'язків не є вичерпним та безмежним i тому окреслюється судом виходячи з конкретних обставин справи. Однак, саме ия «гнучкість» $i \epsilon$ засобом забезпечення ефективного, справедливого, всебічного правосуддя, оскільки адаптуються процесуальні права тата обов'язки учасників справи відповідно до конкретних обставин справи та враховуючи чинне законодавство України.

Ключові слова: господарське судочинство; обов'язки; права; процесуальна форма господарського судочинства; спрощене провадження. 
Ivanov 0. The general procedural rights and obligations of the participants of the simplified claim proceedings

The issue of judicial protection and restoration of their legitimate interests, rights and freedoms, as well as ensuring the realization of legitimate interests, human rights and freedoms is perhaps one of the most pressing issues, so it is necessary to clearly understand the rights and responsibilities of litigants. Mechanism of judicial protection in the form of simplified claim proceedings. According to Article 4 of the Commercial Procedural Code of Ukraine, the right to apply to the commercial court in the prescribed manner is guaranteed by the Commercial Procedural Code of Ukraine. No one may be deprived of the right to have his case heard in a commercial court to whose jurisdiction it is assigned by law. No person may be deprived of the right to participate in the consideration of his case in the manner prescribed by law. Every legal and natural person has the right to be equal before the court and the law, which means that no one can be restricted in their procedural rights and have an expanded scope of responsibilities. The general procedural rights and obligations of the participants of the simplified claim proceedings in the economic process are studied through the prism of the norms of the Constitution of Ukraine and the Commercial Procedural Code of Ukraine. It should be noted that the list and scope of rights and obligations are not exhaustive and unlimited and are therefore determined by the court based on the specific circumstances of the case. However, it is this "flexibility" that is the means of ensuring effective, fair, comprehensive justice, as the procedural rights and responsibilities of the parties are adapted to the specific circumstances of the case and taking into account the current legislation of Ukraine.

Key words: economic justice; duties; rights; processual form of economic legal proceedings; simplified proceedings.

\section{Лiтература}

1. Конституиія України від 28.06 .1996 р. № 254к/96-ВР. Верховна Рада України. Законодавство України. URL: https://goo.gl/8lmc8

2. Господарський процесуальний кодекс України від 06.11.1991 р. № 1798-XII. Верховна Рада України. Законодавство України. URL: https: / / zakon.rada.gov.ua/ laws / show/1798-12\#Text

3. Мильцева В.С. (2018) Електронне судочинство - гарантія ефективності судового проиесу. Актуальні проблеми вітчизняної юриспрудениії. № 2. С. 139-141, с. $139-140$

4. Степанова Т.В. (2017) Процесуальний статус учасників позовного провадження у господарському судочинстві: теоретико-правові та праксеологічні аспекти : монографія. Одеса : Фенікс, 494 c., c. 169

5. Пілат Є. (2010) Право на доступ до інформації як елемент правового статусу особи. Вісник Львівського університету. Серія: юридична. Львів: ЛНУ ім. Івана Франка. Bun. 50. C. 127-132., c. 131.

6. Про судоустрій $i$ статус суддів. Закон України від 02.06.2016 № 1402-VIII. URL: https: / / zakon.rada.gov.ua/laws / show / 1402-19 